\title{
IDENTYFIKACJA PRZEPLYWU DWUFAZOWEGO GAZ-CIECZ OPARTA NA OCENIE ROZMYTEJ OBRAZÓW TOMOGRAFICZNYCH 3D
}

\author{
Tomasz Jaworski, Pawel Fiderek, Radosław Wajman, Robert Banasiak \\ Instytut Informatyki Stosowanej Politechniki Łódzkiej
}

Streszczenie. Prezentowany artykut przedstawia wyniki prac nad systemem automatycznego rozpoznawania przeplywów dwufazowych gaz-ciecz w rurociagach poziomych $i$ pionowych. Opiera się on na logice rozmytej przy ocenie obrazów przestrzennych z tomografii $3 D$ a nastęnie na przyporzadkowaniu uzyskanych ocen do jednej z klas przeptywu.

Słowa kluczowe: logika rozmyta, rozmyta ocena obrazów, przetwarzanie obrazów, obrazy przestrzenne

\section{TWO-PHASE FLOW STRUCTURE IDENTIFICATION BASED ON FUZZY ASSESMENT OF 3D TOMOGRAPHICAL IMAGING}

Abstract. The following paper presents results of research on automated two-phase flow pattern identification, which is based on a fuzzy assessment of registered spatial images. Such images are obtained from $3 D$ tomography reconstruction algorithms and for each a set of fuzzy-based features is calculated. Finally, acquired features are used to classify obtained image to one of flow regime structures.

Keywords: fuzzy logic, fuzzy image assessment, image processing, spatial images

\section{Wprowadzenie}

Niniejszy artykuł prezentuje wykorzystanie metod przetwarzania obrazów wraz z ich oceną na bazie logiki rozmytej w celu identyfikacji struktur przepływu dwufazowego gaz-ciecz w rurociągu pionowym i poziomym. Danymi wejściowymi są przestrzenne (wolumetryczne) obrazy pochodzące z rekonstrukcji pomiarów tomografem pojemnościowym.

Przepływy dwufazowe, przede wszystkim gaz-ciecz, są najczęściej spotykanymi przepływami w instalacjach przemysłowych. Ich cechy sa wspólne, niezależnie od miejsca zastosowania, np. przemysł chemiczny, naftowym czy spożywczy. $\mathrm{W}$ porównaniu $\mathrm{z}$ przepływami jednofazowymi, dwufazowe są znacznie bardziej złożone ze względu na ruchomy i niestabilny interfejs międzyfazowy. Do tej pory opracowano wiele metod pomiaru i obrazowania przepływu, jednak według autorów najbardziej obiecującą rodziną metod są obrazowania nieinwazyjne, m.in. tomografia optyczna, rezystancyjna i pojemnościowa.
Jednym z zadań, jakie można postawić tomografii elektrycznej jest identyfikacja struktur przepływu. Do tej pory, według wiedzy autorów, w celu identyfikacji struktur przepływu wykorzystywano m.in. dwuwymiarowe obrazy tomograficzne $[4,17] \mathrm{z}$ elementami logiki rozmytej $[5,11,12]$, obrazy z szybkiej kamery CCD [3, 16], przetwarzanie surowych pomiarów [14]. Brak jednak badań w kierunku analizy przestrzennych obrazów tomografii 3D z siatką czworościanów. W niniejszym artykule autorzy proponują zastosowanie logiki rozmytej oraz klasyfikatora SVM do identyfikacji struktur przepływu.

\section{Koncepcja algorytmu}

Prezentowany algorytm został przygotowany do identyfikacji struktur przepływów poziomych i pionowych, które uzyskano w ramach badań instalacji pół-przemysłowej w Laboratorium Tomografii Przemysłowej Instytutu Informatyki Stosowanej PŁ. Koncepcja wykonanych badań została omówiona w [2]. Schemat blokowy algorytmu przedstawiono na rysunku 1 .

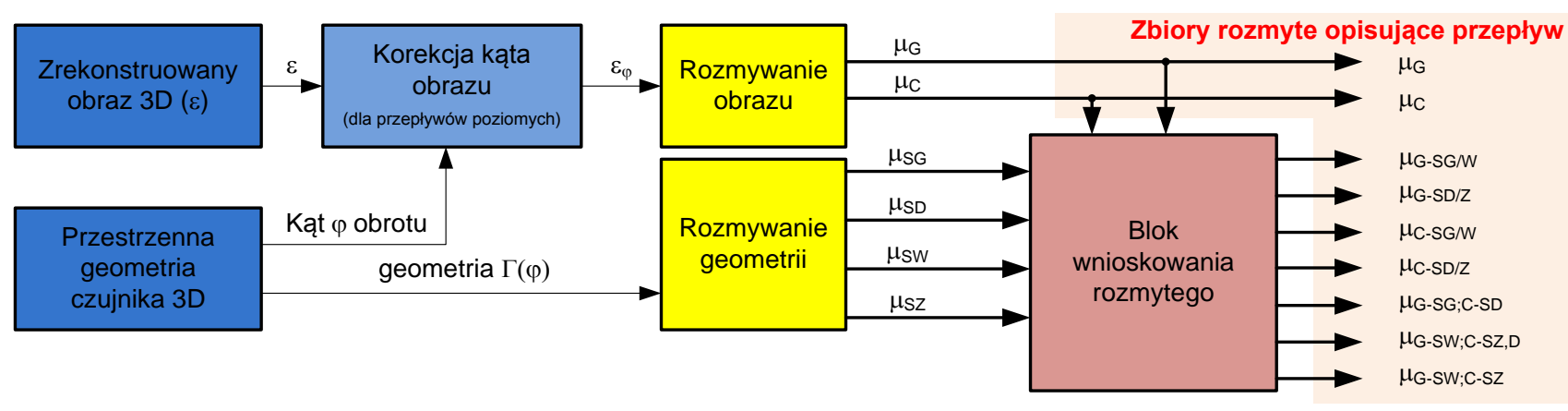

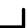

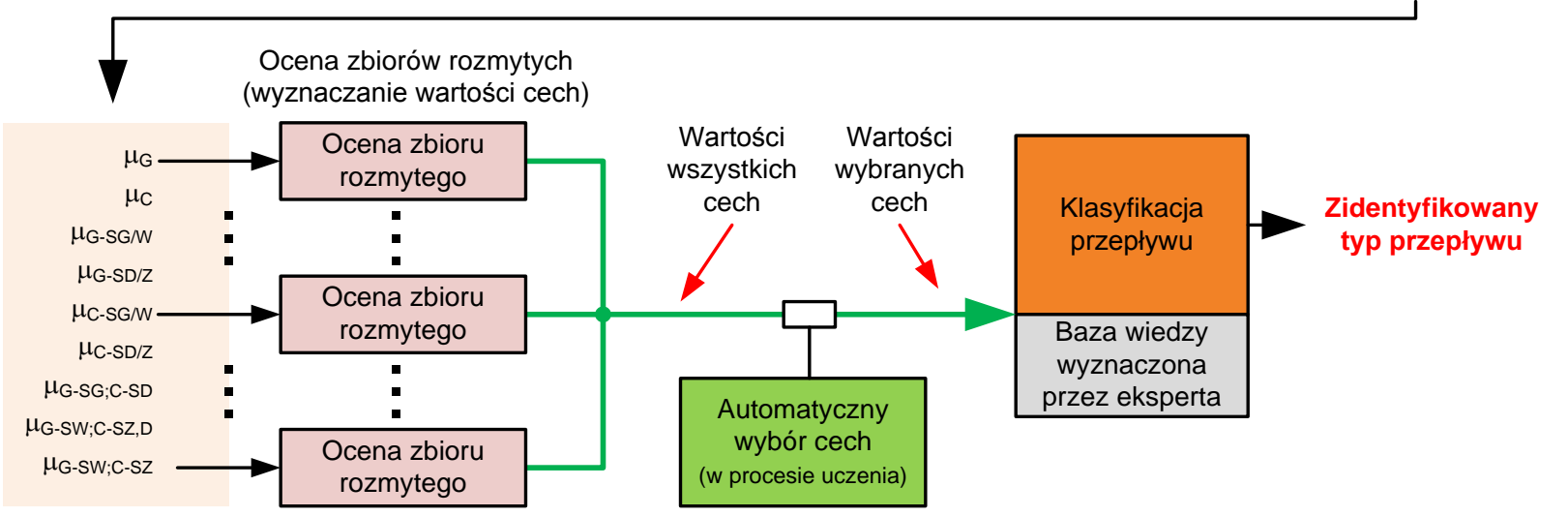

Rys. 1. Schemat blokowy algorytmu identyfikacji struktur przeptywu w rurociagu poziomym i pionowym; $\boldsymbol{G}$ - gaz; $\boldsymbol{C}$ - ciecz; SG - strefa górna; $\boldsymbol{S D}$ - strefa dolna; $\mathbf{S W}$ - strefa wewnętrzne; SZ - strefa zewnętrzna; SG/W - strefa górna lub wewnętrzna; $\mathbf{S D / Z}$ - strefa dolna lub zewnętrzna; $\mathbf{S Z , D}$ - strefa zewnętrzna, dolna 
a)

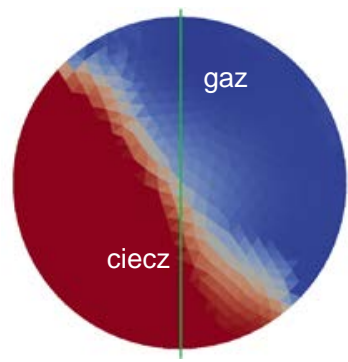

b)

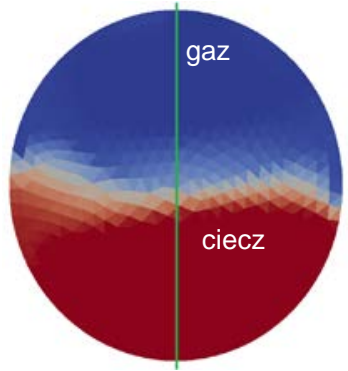

c)

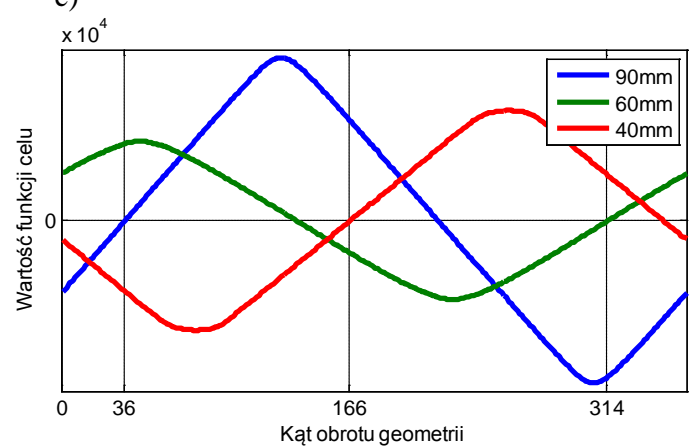

Rys. 2. Projekcja płaszczyzny XY geometrii czujnika (przekrój poprzeczny) dla przepływu poziomego: a) przed obrotem geometrii; b) po obrocie geometrii; c) wykres wartości funkcji celu

Wymagane informacje wejściowe dla algorytmu można podzielić na dwa źródła: zrekonstruowany obraz wraz z geometrią oraz bazę wiedzy, opracowaną przez eksperta zajmującego się przepływami [2]. Zrekonstruowany obraz, oznaczony symbolem $\varepsilon$, jest wynikiem działania algorytmów rekonstrukcji [15]. W przypadku, gdy identyfikowany jest przepływ poziomy, geometria przestrzenna czujnika obracana jest w osi kierunku przepływu o kąt określony przy kalibracji czujnika.

Określenie kąta obrotu geometrii umożliwia zniwelowanie ewentualnego błędu ustawienia czujnika w rurociągu poziomym i ostatecznie ułatwia to używanie rozmytej wartości lingwistycznej „górna/dolna strefa czujnika”, w części wnioskowania rozmytego.

Algorytm określania kąta obrotu geometrii przewiduje, że obrazem wejściowym będzie trójwymiarowa rekonstrukcja wnętrza rurociągu, którego połowę zajmuje ciecz - rysunek 2a (tj. glikol w przypadku przeprowadzonych w ramach projektu eksperymentów).

W celu określenia kąta obrotu geometrii algorytm dokonuje minimalizacji funkcji celu, danej wyrażeniem (1)

$$
\operatorname{Jrot}(\varphi)=\sum_{p \in \Gamma(\varphi)} \operatorname{sign}\left(p_{x}\right) V_{p} I_{p}
$$

gdzie $p$ jest wokselem ${ }^{1}$ trójwymiarowego obrazu $\varepsilon, \Gamma(\varphi)$ jest geometrią obróconą o kąt $\varphi$, $p_{x}$ jest składową $\mathrm{X}$ środka ciężkości woksela $p, V_{p}$ jest objętością woksela $p$ oraz $I_{p}$ jest wartością zrekonstruowanego obrazu $\varepsilon$ w danym wokselu $p$. W trakcie prac uzyskano trzy charakterystyki dla czujników o średnicach $\mathrm{d}_{\mathrm{z}}=90$, $63 \mathrm{i} 40 \mathrm{~mm}$. Zostały one przedstawione na rysunku 2c. Wyrażenie (1) generuje dwa rozwiązania, przy czym właściwe jest tylko to znajdujące się na zboczu narastającym funkcji celu. Po wyznaczeniu kąta obrotu i wizualizacji rekonstrukcji otrzymywany jest obraz przedstawiony na rysunku 2 b. Oczywiście, w przypadku identyfikacji przepływu pionowego korekcja kąta obrotu czujnika nie jest wykonywana.

\section{Blok wnioskowania rozmytego}

Po ewentualnej korekcji geometrii, zrekonstruowany obraz przekazywany jest do bloku wnioskowania rozmytego. Zastosowanie logiki rozmytej [18], jako jednego z elementów procesu identyfikacji, podyktowane zostało naturalną niejednoznacznością wyników rekonstrukcji. Dowolnie wybrany punkt zrekonstruowanego obrazu, na kanwie logiki klasycznej, można interpretować jako „ciecz”, „gaz” lub „stan pośredni”. Ilościowa granica między tymi określeniami jest dyskusyjna a odgórnie narzucone wartości diametralnie wpływają na wynik identyfikacji. Logika rozmyta natomiast w naturalny sposób wykorzystuje niepewność rekonstrukcji, pozwalając na wyznaczenie przynależności danego punktu zarówno do pojęcia „gaz” jak i ,ciecz”. Stan pośredni jest tutaj

\footnotetext{
${ }^{1}$ przestrzenny piksel posiadający objętość - w przypadku opisy-
} wanego algorytmu jest czworościanem „wbudowany” w pojęcie przynależności. Warto nadmienić, że choć przynależność i prawdopodobieństwo operują na zakresie jednostkowym $[0 ; 1]$, to fizyczna interpretacja jest całkowicie odmienna. Dla przykładu, jeśli dla przynależności punktu do zbiorów „gaz”/,ciecz” wynosi 0.5 , to można powiedzieć, że zawiera równocześnie gaz i ciecz w podobnej ilości. Natomiast prawdopodobieństwo 0.5 oznacza, że punkt może być gazem lub cieczą.

Blok wnioskowania rozmytego rozpoczyna swoją pracę od pierwszej fazy - od rozmycia (ang. fuzzification) obrazu, tj. wyznaczenia dwóch zbiorów rozmytych, opisujących obraz wejściowy. Zbiory te, oznaczone odpowiednio gaz (G) i ciecz (C) prezentowane na rysunku 3 opisują stopień, w jakim każdy z punktów obrazu wejściowego można przypisać do kategorii gaz/ciecz.

Druga faza to rozmycie geometrii poprzez utworzenie stref, które można identyfikować wartościami lingwistycznymi, takimi jak: strefa górna (SG), strefa dolna (SD), strefa wewnętrzna (SW), strefa zewnętrzna (SZ). W przypadku czujnika poziomego wartość przynależności jest uwarunkowana procentową wartością składowej Y (wysokość) i przyjmuje wartość od 0 (nie górna strefa $^{2}$ ) do 1 (górna strefa). Funkcje charakterystyczne zbiorów rozmytych zostały przedstawione na rysunku 4a wraz $\mathrm{z}$ wizualizacją zbioru strefa dolna (SD) na rysunku $4 \mathrm{~b}$. Widać na nim, że wartość przynależności przechodzi płynnie od pełnej przynależności (Y maksymalny) do zerowej przynależności (Y minimalny).

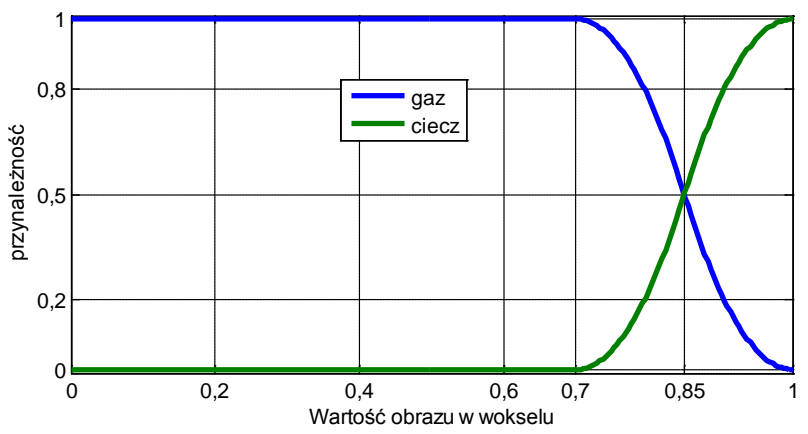

Rys. 3. Funkcje przynależności wykorzystane do rozmycia obrazu wejściowego

Podobnie wygląda rozmywanie geometrii dla czujnika pionowego, gdzie przykład takiego rozmycia został przedstawiony na rysunku 4c. W tym wypadku wartość przynależności do stref wewnętrznej i zewnętrznej zależy od procentowej odległości punktu, dla którego liczona jest przynależność, od środka ciężkości geometrii na płaszczyźnie XY. Wizualizacja 3D na rysunku 4d przedstawia strefę zewnętrzną czujnika.

Po rozmyciu zarówno obrazu jak i geometrii, algorytm identyfikacji realizuje etap wnioskowania, wykorzystując do tego wygenerowane wcześniej zbiory rozmyte. Zaprojektowana baza

\footnotetext{
${ }^{2}$ pojęcie ,nie górna strefa” wcale nie musi oznaczać strefy dolnej
} 
reguł modułu wnioskowania została przedstawiona w tabeli 1 . Pogrubioną czcionką wyróżniono zbiory rozmyte generowane przez poszczególne reguły natomiast kursywą wejściowe zbiory rozmyte.

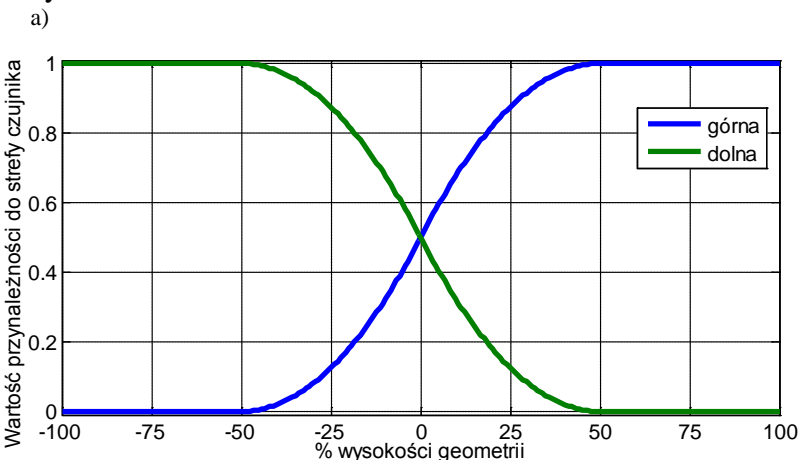

b)

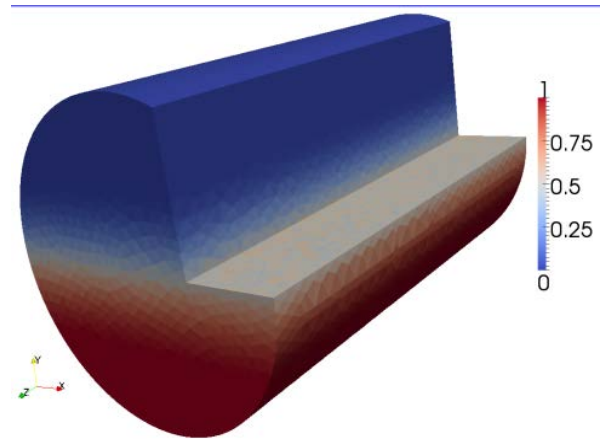

c)

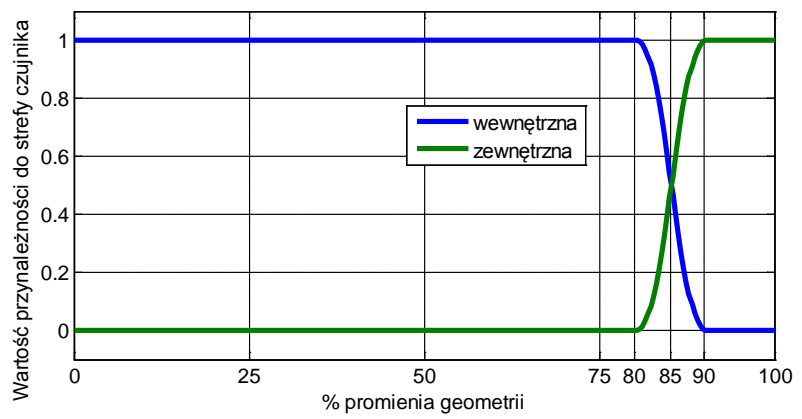

d)

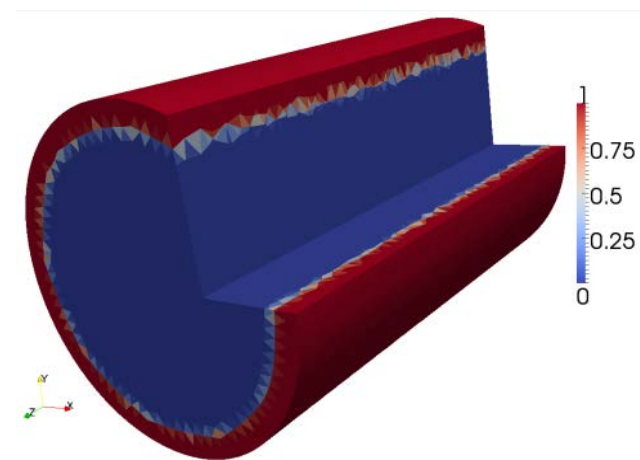

Rys. 4. Rozmywanie geometrii: funkcja charakterystyczna stref: a) górnej i dolnej oraz b) wizualizacja strefy dolnej; c) wewnętrznej i zewnętrznej oraz d) wizualizacja strefy zewnętrznej

Dla tak otrzymanych zbiorów rozmytych wyznaczono wartości cech (zestaw cech), przy czym każdy zbiór oceniany był tym samym zestawem reguł. Oprócz ogólnie przyjętych cech oceny zbioru wartości (średnia, odchylenie standardowe) i zbiorów rozmytych [1] (moc zbioru rozmytego, wielkość nośnika, jądra oraz entropia) autorzy zaproponowali również własne cechy odpowiadające specyfice problemu identyfikacji struktur przepływu. Poniżej zamieszczono listę najważniejszych cech charakteryzujących uzyskane zbiory rozmyte, przy czym czcionką pogrubioną oznaczono cechy zaproponowane przez autorów:

- Liczba kardynalna (moc zbioru) zbioru rozmytego A:

$$
\operatorname{card}(A)=\sum_{x} \mu_{A}(x)
$$

gdzie $A$ to zbiór rozmyty, $\mu_{A}$ to funkcja przynależności (zwana również funkcją charakterystyczną) zbioru rozmytego A.

- Średnia lokalna entropia zbioru rozmytego A:

$$
E_{S L}(A)=\frac{1}{|A|} \sum_{p \in A}\left(\frac{1}{|N B(p)|} \sum_{p \in N B(p)}-S E\left(\mu_{A}(p)\right)\right)
$$

gdzie $A$ to zbiór rozmyty, $N B(\bullet)$ to lista sąsiadów a $\mathrm{SE}(\bullet$ to miara entropii dla konkretnej wartości przynależności, wyrażona poprzez entropię Shannona:

$$
S E(\mu)=\mu \log \mu+(1-\mu) \log (1-\mu)
$$

- Entropia zbioru rozmytego A:

$$
E(A)=\frac{1}{|A|} \sum_{p \in A} S E\left(\mu_{A}(p)\right)
$$

- Entropia rozmyta „AnotA”:

$$
F_{A \bar{A}}(A)=\frac{\operatorname{card}(A \wedge \bar{A})}{\operatorname{card}(A \vee \bar{A})}
$$

gdzie $\bar{A}$ to dopełnienie zbioru rozmytego, najczęściej wyrażone poprzez $\mu_{\bar{A}}=1-\mu_{A}$.

- Jednorodność lokalna maksymalna przestrzennego zbioru rozmytego A:

$$
H_{L M}(A)=\frac{1}{\sum|N B(p)|} \operatorname{std}\left(\bigcup_{p \in A} \max \left(\left\{\mu_{A}(p)-\mu_{A}(q) \mid: q \in N B(p)\right\}\right)\right)
$$

gdzie $\operatorname{std}(\bullet)$ to odchylenie standardowe.

- Jednorodność lokalna przestrzennego zbioru rozmytego A:

$$
H_{L}(A)=\sum_{p \in A} \frac{\operatorname{std}\left(\left\{\mu_{A}(q): q \in N B(p)\right\}\right)}{\left\{\mu_{A}(q): q \in N B(p)\right\}}
$$

- Separacja zbiorów gazu i cieczy w przestrzeni:

$$
S^{r, s}(G, C)=\frac{\sum_{p \in G} p_{Y}^{r} p_{Z}^{s} \mu_{G}(p)}{\operatorname{card}(G)}-\frac{\sum_{q \in C} q_{Y}^{r} q_{Z}^{s} \mu_{C}(q)}{\operatorname{card}(C)}
$$

gdzie $P_{Y}$ oraz $P_{Z}$ to składowe $Y$ oraz $Z$ środka woksela p. W implementacji wykorzystano $S^{1,0}$ dla przepływów poziomych i $S^{0,1}$ dla przepływów pionowych.

Tabela 1. Baza regut wnioskowania rozmytego i wyrażeń akumulujących

\begin{tabular}{|c|}
\hline Blok 1 (wnioskowanie - zastosowana implikacja rozmyta) \\
\hline Jeśli strefa jest górna i obraz jest gazem to gaz u góry (G-SG); \\
Jeśli strefa jest dolna i obraz jest gazem to gaz na dole (G-SD); \\
Jeśli strefa jest górna i obraz jest ciecza to ciecz u góry (C-SG); \\
Jeśli strefa jest dolna i obraz jest ciecza to ciecz na dole (C-SD); \\
\hline Blok 2 (wnioskowanie - zastosowana implikacja rozmyta) \\
\hline Jeśli strefa jest wewnętrzna i obraz jest gazem to gaz jest wewnątrz (G-SW); \\
Jeśli strefa jest zewnętrzna i obraz jest gazem to gaz jest na zewnątrz (G-SZ); \\
Jeśli strefa jest wewnętrzna i obraz jest cieczq to ciecz jest wewnątrz (C-SW); \\
Jeśli strefa jest zewnętrzna i obraz jest cieczq to ciecz jest na zewnątrz (C-SZ); \\
\hline Blok 3 (akumulacja - zastosowany iloczyn rozmyty) \\
\hline gaz u góry $(G-S G)$ i ciecz u dotu $(C-S D) \rightarrow$ \\
gaz u góry, ciecz na dole (G-SG;C-SD) \\
gaz jest wewnątrz (G-SW) i ciecz jest na zewnątrz (C-SZ) $\rightarrow$ \\
gaz wewnątrz, ciecz na zewnątrz (G-SW;C-SZ) \\
gaz jest wewnątrz (G-SW) i ciecz jest na zewnatrz (C-SZ) i strefa jest dolna $(S D) \rightarrow$ \\
gaz wewnątrz, ciecz w strefie dolnej/zewnętrznej (G-SW;C-SZ,D)
\end{tabular}

\section{Blok klasyfikatorów}

Mając wyznaczone wartości cech dla obrazów z przepływów eksperymentalnych, autorzy przystąpili do przygotowania zbiorów uczących oraz testujących klasyfikator. Analiza odbywała się poprzez indywidualny opis, wykonywany przez eksperta, poszczególnych obrazów zrekonstruowanych w ramach badań opisanych w [15]. W ramach analizy obrazów przestrzennych 
wyróżniono szereg klas odpowiadających obserwowalnym strukturom przepływów. Zestaw klas został przedstawiony w tabeli 2. Każdy $\mathrm{z}$ obrazów został zakwalifikowany przez eksperta do jednej $z$ klas.

Tabela 2. Lista klas rozpoznawanych struktur z podziatem na średnice i typy przeptywów

\begin{tabular}{|c|c|c|}
\hline Typ & Średnica & Klasy \\
\hline Poziomy & $\begin{array}{c}90 \mathrm{~mm}, 63 \mathrm{~mm}, \\
40 \mathrm{~mm}\end{array}$ & $\begin{array}{c}\text { Tylko ciecz (1), Warstwowy (2), } \\
\text { Rzutowy (3), Pęcherzykowy (4) }\end{array}$ \\
\hline Pionowy & $\begin{array}{c}90 \mathrm{~mm}, 63 \mathrm{~mm}, \\
40 \mathrm{~mm}\end{array}$ & Rzutowy (1), Pianowy (2), \\
& Pierścieniowy (3), Tylko ciecz (4) \\
\hline
\end{tabular}

Jako klasyfikator wykorzystano technikę wektorów podtrzymujących [6] SVM (ang. Support Vector Machine), znaną w polskim tłumaczeniu również jako Maszynę Wektorów Nośnych/Podpierających. Ideą klasyfikatora SVM jest rozdzielenie punktów, należących do dwóch różnych klas (etykiety 1 i -1 ), za pomocą hiperpłaszczyzny określonej równaniem (10). Punkty te, sa obrazami opisanymi przez wektory cech o identycznej długości.

$$
\overrightarrow{\mathbf{w}} \cdot \overrightarrow{\mathbf{x}}-b=0
$$

gdzie wektor $\overrightarrow{\mathbf{w}}$ jest normalnym do hiperpłaszczyzny a skalar $b$ jej przesunięciem. Algorytm znajduje wartości wektora $\overrightarrow{\mathbf{w}}$ i $b$ poprzez znalezienie największego marginesu rozdzielającego, wyrażonego poprzez $2 /\|\overrightarrow{\mathbf{w}}\|$. Odbywa się to poprzez znalezienie minimum $\|\overrightarrow{\mathbf{w}}\|^{2}$, spełniającego warunek (11).

$$
y_{i}\left(\mathbf{w} \cdot \mathbf{s}_{i}-b\right) \geq 1
$$

gdzie $y_{i}$ to etykieta klasy $\{-1,1\}$, a $s_{i}$ to i-ty wektor wspierający, na którym dodatnia bądź ujemna strona marginesu ma się opierać.

Ponieważ klasyfikator ten jest $\mathrm{z}$ natury dwuklasowy (etykiety klas to $1 \mathrm{i}-1$ ), w celu uzyskania klasyfikatora wieloklasowego, wykorzystano metodę ONE-versus-ALL [13]. Polega ona na utworzeniu $\mathrm{K}$ klasyfikatorów dla $\mathrm{K}$ klas, gdzie każdy z klasyfikatorów wyznacza hiperpłaszczyznę separującą swoją klasę od pozostałych punktów. Ostateczna decyzja polega na wybraniu klasy, dla której klasyfikowany punkt jest położony najdalej od hiperpłaszczyzny separującej, w kierunku normalnej do tej płaszczyzny.

Ze względu na dużą ilość wartości cech opisujących każdy z obrazów (302 elementy wektora), autorzy wykorzystali metodę automatycznego doboru cech SVM-RFE [9]. Jej celem jest wyeliminowanie cech nieznaczących i zwiększenie wydajności etapu klasyfikacji. Ograniczenie ilości cech istotnych, pozwoliło również na zmniejszenie nakładu obliczeniowego, a tym samym zwiększyło wydajność całego procesu.

Poza tym, implementując klasyfikator SVM dokonano porównania wyników klasyfikacji z FCM (ang. Fuzzy C-Means), będącym najczęściej stosowanym algorytmem grupowania rozmytego [7]. Podstawową różnicą między algorytmem FCM a SVM jest możliwość przypisania jednego punktu do różnych klas z odpowiednimi dla nich stopniami przynależności. W trakcie porównywania wyników przyjęto, że obraz należy do tej klasy, dla której jego wartość przynależności jest największa. Ideą algorytmu FCM jest minimalizacja funkcji celu, podana w wyrażeniu (12):

$$
J(\mathbf{X} ; \mathbf{U}, \mathbf{V})=\sum_{i=1}^{C} \sum_{k=1}^{|\mathbf{X}|} \mu_{i k}^{m}\left(\mathbf{x}_{k}-\mathbf{v}_{i}\right)^{T} \mathbf{A}\left(\mathbf{x}_{k}-\mathbf{v}_{i}\right)
$$

gdzie:

$U-\mathbf{U}=\left\{\mu_{i k}\right\}-$ macierz podziału zbioru punktów $\mathbf{X}=\left\{\mathbf{X}_{k}\right\}$,

$X$ - zbiór punktów $\mathrm{x}_{\mathrm{k}}$,

$\mathrm{C}-$ ilość grup, $\mathrm{k}$ - numer punktu,

$V-\mathbf{V}=\left\{\mathbf{v}_{1}, \mathbf{v}_{2}, \ldots, \mathbf{v}_{C}\right\}-$ macierz przechowująca współrzędne środków grup $\mathbf{V}_{i}$, zwanych również prototypami,

$\left(\mathbf{x}_{k}-\mathbf{v}_{i}\right)^{T} \mathbf{A}\left(\mathbf{x}_{k}-\mathbf{v}_{i}\right)$ - wyrażenie pozwalające obliczyć odległość między punktem $\mathbf{x}_{k}$ a środkiem grupy $\mathbf{V}_{i}$,

A - A jest macierzą indukującą miarę odległości. W przypadku algorytmu FCM jest to macierz jednostkowa.

\section{Klasyfikacja zbioru uczącego}

Dysponując implementacjami powyższych elementów systemu oraz zbiorami danych uczących i testujących, autorzy przystąpili do etapu uczenia klasyfikatorów poszczególnych wzorców przepływów. Tabela 3 przedstawia wyniki uczenia i klasyfikacji wybranych obrazów uczących dla poszczególnych eksperymentów, przy czym proces ten był weryfikowany metodą Minus jednego elementu (ang. Leave-One-Out) [8].

Wyniki klasyfikacji testowej, otrzymane $\mathrm{w}$ trakcie uczenia, zarówno dla klasyfikatora SVM jak i FCM, zostały przedstawione w postaci macierzy pomyłek [10] (ang. confussion matrix). Jako dane uczące wykorzystano wyniki badań, opisane w [15]. Dane te były w postaci zrekonstruowanych obrazów dla przepływów różnego typu i zostały poddane ręcznej ocenie przez eksperta $\mathrm{z}$ dziedziny inżynierii procesowej a następnie wykorzystane jako dane uczące dla opisywanej metody.

Wiersze macierzy oznaczają spodziewany rezultat klasyfikacji, natomiast kolumny - rzeczywisty (uzyskany z algorytmów SVM/FCM). Każdy z wierszy posiada etykietę oraz identyfikator nadany przez eksperta.

Dla lepszej czytelności, identyfikatory posiadają tylko nazwy kolumn. Jakość klasyfikacji etapu uczenia (również etapu klasyfikacji testowej) dla obu klasyfikatorów określono przez trzy miary ewaluacji:

- czułość (ang. sensitivity), określona wzorem (12), oznaczająca prawdopodobieństwo klasyfikacji danego obrazu do klasy wyznaczonej przez eksperta (prawdopodobieństwo poprawnej klasyfikacji),

$$
M_{\text {czulosc }}=\frac{T P}{T P+F N}
$$

- odrębność (ang. specifity) lub swoistość, określona wzorem (13), oznaczająca prawdopodobieństwo niezaklasyfikowania danego punktu do klasy, do której nie należy (według eksperta),

$$
M_{\text {specyficznosc }}=\frac{T N}{T N+F P}
$$

- precyzja (ang. total accuracy) określona wzorem (14), oznaczająca prawdopodobieństwo prawidłowej klasyfikacji danego punktu,

$$
M_{\text {dokladnosc }}=\frac{T P+T N}{T P+F P+F N+T N}
$$

gdzie wartości TP, TN, FP, FN w powyższych wyrażeniach wyznaczane są dla poszczególnych błędnych macierzy pomyłek. Ich znaczenia podano poniżej:

TP - (ang. True Positive) - ilość klasyfikacji punktów z klasy X do klasy $\mathrm{X}$,

TN - (ang. True Negative) - ilość klasyfikacji punktów spoza klasy X do klas innych niż X,

FP - (ang. False Positive) - ilość klasyfikacji punktów spoza klasy $\mathrm{X}$ do klasy $\mathrm{X}$

FN - (ang. False Negative) - ilość klasyfikacji punktów z klasy X do klas innych niż X. 
Tabela 3. Wynik efektywności uczenia klasyfikatora (kolorem szarym oznaczono klasyfikator bliższy decyzjom eksperta; kolorem żóttym oznaczono te same poziomy prawdopodobieństwa dla obu klasyfikatorów)

\begin{tabular}{|c|c|c|c|c|c|c|c|c|c|c|c|c|c|c|c|c|c|c|}
\hline \multirow{3}{*}{ 总 } & \multirow{3}{*}{ 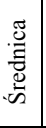 } & \multirow{3}{*}{ 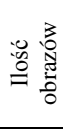 } & \multicolumn{16}{|c|}{ Nazwa klasy (numer klasy) } \\
\hline & & & \multirow{2}{*}{$\begin{array}{c}\text { Określone przez } \\
\text { eksperta }\end{array}$} & \multicolumn{7}{|c|}{ Klasyfikator SVM } & \multicolumn{7}{|c|}{ Klasyfikator FCM } & \multirow{2}{*}{ Raze } \\
\hline & & & & 1 & 2 & 3 & 4 & Czułość & Spec. & Dokład. & 1 & 2 & 3 & 4 & Czułość & Spec. & Dokład. & \\
\hline \multirow{12}{*}{$\begin{array}{l}\overrightarrow{\mathrm{O}} \\
\stackrel{\mathrm{O}}{\mathrm{O}} \\
\mathrm{O}\end{array}$} & & \multirow{4}{*}{ छें } & Tylko ciecz (1) & 48 & 1 & 1 & 0 & $96.00 \%$ & $99.33 \%$ & $98.50 \%$ & 34 & 1 & 0 & 15 & $68.00 \%$ & $98.00 \%$ & $90.50 \%$ & 50 \\
\hline & 豆 & & Warstwowy (2) & 0 & 48 & 2 & 0 & $96.00 \%$ & $98.00 \%$ & $97.50 \%$ & 0 & 49 & 1 & 0 & $98.00 \%$ & $88.67 \%$ & $91.00 \%$ & 50 \\
\hline & & & Rzutowy (3) & 1 & 2 & 47 & 0 & $94.00 \%$ & $98.00 \%$ & $97.00 \%$ & 3 & 16 & 31 & 0 & $62.00 \%$ & $99.33 \%$ & $90.00 \%$ & 50 \\
\hline & & & Pęcherzykowy (4) & 0 & 0 & 0 & 50 & $100.00 \%$ & $100.00 \%$ & $100.00 \%$ & 0 & 0 & 0 & 50 & $100.00 \%$ & $90.00 \%$ & $92.50 \%$ & 50 \\
\hline & & \multirow{4}{*}{ बㄱ } & Tylko ciecz (1) & 49 & 0 & 1 & 0 & $98.00 \%$ & $97.87 \%$ & $97.91 \%$ & 49 & 0 & 1 & 0 & $98.00 \%$ & $94.33 \%$ & $95.29 \%$ & 50 \\
\hline & 言 & & Warstwowy (2) & 0 & 48 & 2 & 0 & $96.00 \%$ & $95.04 \%$ & $95.29 \%$ & 1 & 49 & 0 & 0 & $98.00 \%$ & $92.20 \%$ & $93.72 \%$ & 50 \\
\hline & & & Rzutowy (3) & 3 & 7 & 39 & 1 & $78.00 \%$ & $96.45 \%$ & $91.62 \%$ & 7 & 11 & 27 & 5 & $54.00 \%$ & $99.29 \%$ & $87.43 \%$ & 50 \\
\hline & & & Pęcherzykowy (4) & 0 & 0 & 2 & 39 & $95.12 \%$ & $99.33 \%$ & $98.43 \%$ & 0 & 0 & 0 & 41 & $100.00 \%$ & $96.67 \%$ & $97.38 \%$ & 41 \\
\hline & \multirow{4}{*}{ 全 } & \multirow{4}{*}{$\stackrel{\text { g }}{\sigma}$} & Tylko ciecz (1) & 43 & 0 & 0 & 0 & $100.00 \%$ & $99.33 \%$ & $99.48 \%$ & 37 & 1 & 5 & 0 & $86.05 \%$ & $99.33 \%$ & $96.37 \%$ & 43 \\
\hline & & & Warstwowy (2) & 1 & 49 & 0 & 0 & $98.00 \%$ & $100.00 \%$ & $99.48 \%$ & 1 & 48 & 1 & 0 & $96.00 \%$ & $99.30 \%$ & $98.45 \%$ & 50 \\
\hline & & & Rzutowy (3) & 0 & 0 & 50 & 0 & $100.00 \%$ & $100.00 \%$ & $100.00 \%$ & 0 & 0 & 50 & 0 & $100.00 \%$ & $95.80 \%$ & $96.89 \%$ & 50 \\
\hline & & & Pęcherzykowy (4) & 0 & 0 & 0 & 50 & $100.00 \%$ & $100.00 \%$ & $100.00 \%$ & 0 & 0 & 0 & 50 & $100.00 \%$ & $100.00 \%$ & $100.00 \%$ & 50 \\
\hline \multirow{12}{*}{$\begin{array}{l}\hat{3} \\
0 \\
\vdots \\
. \\
.0\end{array}$} & \multirow{4}{*}{ 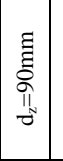 } & \multirow{4}{*}{$\stackrel{\sim}{~}$} & Rzutowy (1) & 32 & 13 & 3 & 2 & $64.00 \%$ & $89.33 \%$ & $83.00 \%$ & 23 & 22 & 4 & 1 & $46.00 \%$ & $84.00 \%$ & $74.50 \%$ & 50 \\
\hline & & & Pianowy (2) & 11 & 39 & 0 & 0 & $78.00 \%$ & $88.67 \%$ & $86.00 \%$ & 20 & 30 & 0 & 0 & $60.00 \%$ & $83.33 \%$ & $77.50 \%$ & 50 \\
\hline & & & Pierścieniowy (3) & 3 & 4 & 17 & 26 & $34.00 \%$ & $79.33 \%$ & $68.00 \%$ & 4 & 3 & 20 & 23 & $40.00 \%$ & $88.67 \%$ & $76.50 \%$ & 50 \\
\hline & & & Tylko ciecz (4) & 2 & 0 & 28 & 20 & $40.00 \%$ & $81.33 \%$ & $71.00 \%$ & 0 & 0 & 13 & 37 & $74.00 \%$ & $84.00 \%$ & $81.50 \%$ & 50 \\
\hline & & \multirow{4}{*}{ 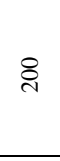 } & Rzutowy (1) & 37 & 1 & 12 & 0 & $74.00 \%$ & $93.33 \%$ & $88.50 \%$ & 21 & 12 & 17 & 0 & $42.00 \%$ & $76.00 \%$ & $67.50 \%$ & 50 \\
\hline & 言 & & Pianowy (2) & 2 & 43 & 5 & 0 & $86.00 \%$ & $95.33 \%$ & $93.00 \%$ & 2 & 48 & 0 & 0 & $96.00 \%$ & $89.33 \%$ & $91.00 \%$ & 50 \\
\hline & $i_{\infty}$ & & Pierścieniowy (3) & 8 & 6 & 35 & 1 & $70.00 \%$ & $86.67 \%$ & $82.50 \%$ & 33 & 4 & 13 & 0 & $26.00 \%$ & $75.33 \%$ & $63.00 \%$ & 50 \\
\hline & & & Tylko ciecz (4) & 0 & 0 & 3 & 47 & $94.00 \%$ & $99.33 \%$ & $98.00 \%$ & 1 & 0 & 20 & 29 & $58.00 \%$ & $100.00 \%$ & $89.50 \%$ & 50 \\
\hline & \multirow{4}{*}{, } & \multirow{4}{*}{$\stackrel{\infty}{\infty}$} & Rzutowy (1) & 20 & 9 & 13 & 8 & $40.00 \%$ & $74.26 \%$ & $65.05 \%$ & 32 & 7 & 2 & 9 & $64.00 \%$ & $66.91 \%$ & $66.13 \%$ & 50 \\
\hline & & & Pianowy (2) & 14 & 20 & 4 & 12 & $40.00 \%$ & $82.35 \%$ & $70.97 \%$ & 5 & 20 & 7 & 18 & $40.00 \%$ & $83.09 \%$ & $71.51 \%$ & 50 \\
\hline & & & Pierścieniowy (3) & 13 & 3 & 34 & 0 & $68.00 \%$ & $87.50 \%$ & $82.26 \%$ & 40 & 0 & 10 & 0 & $20.00 \%$ & $93.38 \%$ & $73.66 \%$ & 50 \\
\hline & & & Tylko ciecz (4) & 8 & 12 & 0 & 16 & $44.44 \%$ & $86.67 \%$ & $78.49 \%$ & 0 & 16 & 0 & 20 & $55.56 \%$ & $82.00 \%$ & $76.88 \%$ & 36 \\
\hline
\end{tabular}

Tabela 4. Wyniki klasyfikacji obrazów przeznaczonych do testowania klasyfikatora (kolorem szarym oznaczono klasyfikator bliższy decyzjom eksperta; kolorem żóltym oznaczono te same poziomy prawdopodobieństwa dla obu klasyfikatorów)

\begin{tabular}{|c|c|c|c|c|c|c|c|c|c|c|c|c|c|c|c|c|c|c|}
\hline \multirow{3}{*}{ 荨 } & \multirow{3}{*}{ 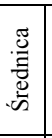 } & \multirow{3}{*}{ 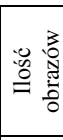 } & \multicolumn{16}{|c|}{ Nazwa klasy (numer klasy) } \\
\hline & & & \multirow{2}{*}{$\begin{array}{c}\text { Określone przez } \\
\text { eksperta }\end{array}$} & \multicolumn{7}{|c|}{ Klasyfikator SVM } & \multicolumn{7}{|c|}{ Klasyfikator FCM } & \multirow{2}{*}{ Razen } \\
\hline & & & & 1 & 2 & 3 & 4 & Czułość & Spec. & Dokład. & 1 & 2 & 3 & 4 & Czułość & Spec. & Dokład. & \\
\hline \multirow{12}{*}{ 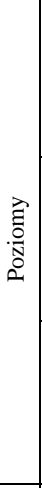 } & \multirow{3}{*}{ 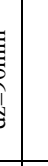 } & \multirow{4}{*}{ 喿 } & Tylko ciecz (1) & 1570 & 0 & 0 & 6 & $99.62 \%$ & $100.00 \%$ & $99.87 \%$ & 1574 & 0 & 0 & 2 & $99.87 \%$ & $99.83 \%$ & $99.85 \%$ & 1576 \\
\hline & & & Warstwowy (2) & 0 & 2280 & 146 & 1 & $93.94 \%$ & $100.00 \%$ & $96.80 \%$ & 0 & 1034 & 1393 & 0 & $42.60 \%$ & $100.00 \%$ & $69.65 \%$ & 2427 \\
\hline & & & Rzutowy (3) & 0 & 0 & 170 & 2 & $98.84 \%$ & $96.58 \%$ & $96.67 \%$ & 0 & 0 & 171 & 1 & $99.42 \%$ & $67.22 \%$ & $68.43 \%$ & 172 \\
\hline & & & Pęcherzykowy (4) & 0 & 0 & 5 & 410 & $98.80 \%$ & $99.78 \%$ & $99.69 \%$ & 5 & 0 & 55 & 355 & $85.54 \%$ & $99.93 \%$ & $98.63 \%$ & 415 \\
\hline & & \multirow{4}{*}{$\overrightarrow{\vec{N}}$} & Tylko ciecz (1) & 686 & 21 & 48 & 1 & $90.74 \%$ & $99.55 \%$ & $96.67 \%$ & 656 & 9 & 87 & 4 & $86.77 \%$ & $96.46 \%$ & $93.29 \%$ & 756 \\
\hline & 音 & & Warstwowy (2) & 0 & 1340 & 28 & 0 & $97.95 \%$ & $96.29 \%$ & $97.27 \%$ & 34 & 1313 & 20 & 1 & $95.98 \%$ & $95.02 \%$ & $95.59 \%$ & 1368 \\
\hline & \begin{tabular}{|l|}
0 \\
0 \\
0
\end{tabular} & & Rzutowy (3) & 7 & 14 & 122 & 3 & $83.56 \%$ & $96.49 \%$ & $95.67 \%$ & 21 & 38 & 69 & 18 & $47.26 \%$ & $95.06 \%$ & $92.04 \%$ & 146 \\
\hline & & & Pęcherzykowy (4) & 0 & 0 & 0 & 41 & $100.00 \%$ & $99.82 \%$ & $99.83 \%$ & 0 & 0 & 0 & 41 & $100.00 \%$ & $98.99 \%$ & $99.00 \%$ & 41 \\
\hline & & \multirow{4}{*}{ 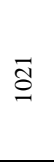 } & Tylko ciecz (1) & 43 & 0 & 0 & 0 & $100.00 \%$ & $98.06 \%$ & $98.14 \%$ & 37 & 1 & 5 & 0 & $86.05 \%$ & $99.69 \%$ & $99.12 \%$ & 43 \\
\hline & 章 & & Warstwowy (2) & 16 & 550 & 0 & 0 & $97.17 \%$ & $99.78 \%$ & $98.33 \%$ & 2 & 549 & 13 & 2 & $97.00 \%$ & $99.56 \%$ & $98.14 \%$ & 566 \\
\hline & $\begin{array}{l}\pi \\
\prod_{0}^{\pi} \\
0\end{array}$ & & Rzutowy (3) & 3 & 1 & 303 & 1 & $98.38 \%$ & $100.00 \%$ & $99.51 \%$ & 1 & 1 & 306 & 0 & $99.35 \%$ & $97.48 \%$ & $98.04 \%$ & 308 \\
\hline & & & Pęcherzykowy (4) & 0 & 0 & 0 & 104 & $100.00 \%$ & $99.89 \%$ & $99.90 \%$ & 0 & 0 & 0 & 104 & $100.00 \%$ & $99.78 \%$ & $99.80 \%$ & 104 \\
\hline \multirow{12}{*}{$\begin{array}{l}3 \\
\vdots \\
0 \\
0 \\
0\end{array}$} & \multirow{4}{*}{ 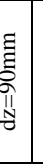 } & \multirow{4}{*}{ ஓ } & Rzutowy (1) & 133 & 19 & 24 & 10 & $71.51 \%$ & $93.08 \%$ & $88.59 \%$ & 82 & 60 & 31 & 13 & $44.09 \%$ & $81.36 \%$ & $73.60 \%$ & 186 \\
\hline & & & Pianowy (2) & 34 & 193 & 10 & 0 & $81.43 \%$ & $94.82 \%$ & $91.28 \%$ & 101 & 136 & 0 & 0 & $57.38 \%$ & $88.74 \%$ & $80.43 \%$ & 237 \\
\hline & & & Pierścieniowy (3) & 10 & 15 & 157 & 83 & $59.25 \%$ & $82.51 \%$ & $75.62 \%$ & 25 & 14 & 115 & 111 & $43.40 \%$ & $86.49 \%$ & $73.71 \%$ & 265 \\
\hline & & & Tylko ciecz (4) & 5 & 0 & 76 & 125 & $60.68 \%$ & $86.48 \%$ & $80.54 \%$ & 6 & 0 & 54 & 146 & $70.87 \%$ & $81.98 \%$ & $79.42 \%$ & 206 \\
\hline & & \multirow{4}{*}{$\stackrel{\infty}{\mathbb{N}}$} & Rzutowy (1) & 187 & 8 & 23 & 0 & $85.78 \%$ & $96.04 \%$ & $93.05 \%$ & 98 & 50 & 70 & 0 & $44.95 \%$ & $80.94 \%$ & $70.45 \%$ & 218 \\
\hline & & & Pianowy (2) & 1 & 83 & 1 & 0 & $97.65 \%$ & $97.74 \%$ & $97.73 \%$ & 2 & 83 & 0 & 0 & $97.65 \%$ & $90.95 \%$ & $91.71 \%$ & 85 \\
\hline & & & Pierścieniowy (3) & 12 & 7 & 122 & 3 & $84.72 \%$ & $93.38 \%$ & $91.71 \%$ & 93 & 10 & 41 & 0 & $28.47 \%$ & $68.71 \%$ & $60.96 \%$ & 144 \\
\hline & & & Tylko ciecz (4) & 8 & 0 & 16 & 277 & $92.03 \%$ & $99.33 \%$ & $96.39 \%$ & 6 & 0 & 119 & 176 & $58.47 \%$ & $100.00 \%$ & $83.29 \%$ & 301 \\
\hline & \multirow{4}{*}{ 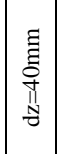 } & \multirow{4}{*}{ 守 } & Rzutowy (1) & 55 & 4 & 6 & 7 & $76.39 \%$ & $97.62 \%$ & $91.25 \%$ & 43 & 11 & 3 & 15 & $59.72 \%$ & $70.83 \%$ & $67.50 \%$ & 72 \\
\hline & & & Pianowy (2) & 3 & 67 & 2 & 9 & $82.72 \%$ & $97.48 \%$ & $92.50 \%$ & 8 & 30 & 12 & 31 & $37.04 \%$ & $83.02 \%$ & $67.50 \%$ & 81 \\
\hline & & & Pierścieniowy (3) & 1 & 0 & 50 & 0 & $98.04 \%$ & $95.77 \%$ & $96.25 \%$ & 41 & 0 & 10 & 0 & $19.61 \%$ & $92.06 \%$ & $76.67 \%$ & 51 \\
\hline & & & Tylko ciecz (4) & 0 & 0 & 0 & 36 & $100.00 \%$ & $92.16 \%$ & $93.33 \%$ & 0 & 16 & 0 & 20 & $55.56 \%$ & $77.45 \%$ & $74.17 \%$ & 36 \\
\hline
\end{tabular}




\subsection{Wyniki klasyfikacji dla zbioru uczącego}

W przypadku eksperymentów z klasyfikacją przepływów poziomych widać, że klasyfikator SVM jest odpowiednim narzędziem (dokładność klasyfikacji wyższa od FCM dla wszystkich średnic). Nie dyskwalifikuje to jednak klasyfikatora FCM, gdyż jego dokładność (poza przypadkiem przepływu rzutowego $/ \mathrm{d}_{\mathrm{z}}=63 \mathrm{~mm}$ ) utrzymuje się powyżej $90 \%$. Tak niski wynik dokładności klasyfikacji, na poziomie $87 \%$ można tłumaczyć podobieństwem obrazów tomograficznych przepływu rzutowego do warstwowego. Warto również zwrócić uwagę na bardzo dobre rozróżnienie przepływu pęcherzykowego od rury pełnej cieczy. Podczas przygotowywania danych testowych ekspert często nie mógł się zdecydować, do której z tych klas dany przepływ zaliczyć

Widocznie niższą dokładność klasyfikacji w etapie nauki uzyskano dla przepływów pionowych. Tutaj ogromnym utrudnieniem okazał się efekt cofania się struktur. Również wiele obrazów zostało bez jakiejkolwiek klasyfikacji ze strony eksperta ze względu na brak wizualnej przynależności do jakiejkolwiek rozpoznawalnej struktury. W tym wypadku najniższą dokładność klasyfikacji uzyskał przepływ rzutowy dla czujnika o średnicy $\mathrm{d}_{\mathrm{z}}=40 \mathrm{~mm}$. Ze względu na średnicę oraz naturę zjawiska praktycznie każdy obraz, uzyskany za pomocą tomografu, przypominał przepływ rzutowy

\subsection{Wyniki klasyfikacji zbioru testującego}

Tabela 4 przedstawia wyniki klasyfikacji obrazów testowych zidentyfikowanych przez eksperta. W przypadku identyfikacji na danych testujących autorzy uzyskali wyniki podobne do klasyfikacji danych uczących. Klasyfikator SVM okazał się dobrze wybranym narzędziem do identyfikacji przepływów z obu typów czujników. Tylko w jednym przypadku, dla czujnika poziomego $\mathrm{d}_{\mathrm{z}}=40 \mathrm{~mm} \mathrm{i}$ identyfikacji rury wypełnionej glikolem, uzyskano dokładność $98.14 \%$ (o $0.8 \%$ mniejszą niż w przypadku zastosowania klasyfikatora FCM). Można to wyjaśnić efektem „napowietrzenia” glikolu, który ze względu na swoją lepkość tworzył zawiesinę gazu w cieczy. Efekt ten był również niekorzystny $\mathrm{w}$ procesie kalibracji i normalizacji pomiarów czujnika ze względu na zawsze istniejącą, resztkową ilość gazu w cieczy.

\subsection{Przykłady przepływów}

$\mathrm{Na}$ rysunku 5, zamieszczono przykładowe trójwymiarowe obrazy przepływów, analizowanych przez eksperta.

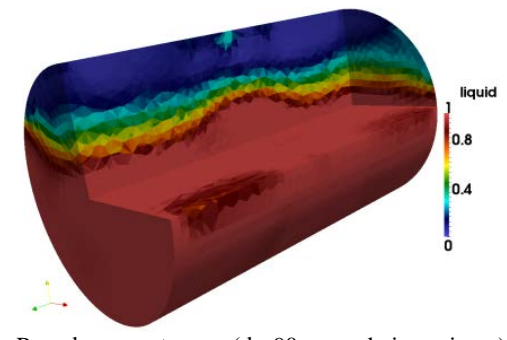

Przepływ warstwowy $\left(\mathrm{d}_{\mathrm{z}}=90 \mathrm{~mm}\right.$, sekcja pozioma $)$

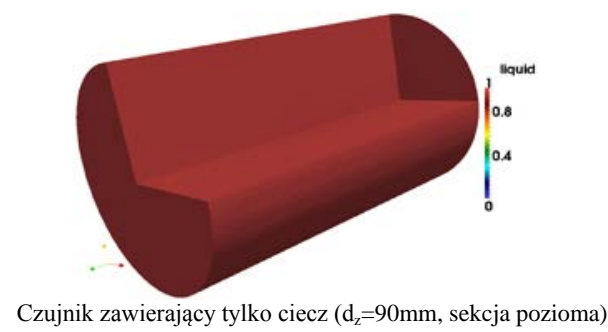

Rys. 5. Trójwymiarowe tomogramy struktur przepływów wraz z opisem uzyskanym przez eksperta
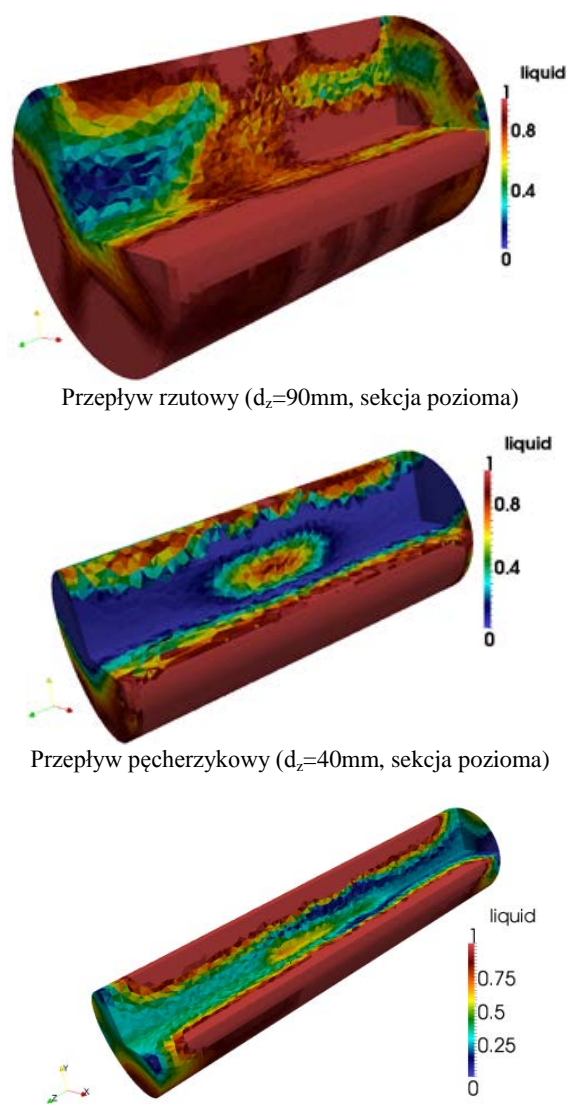

Przepływ pęcherzykowy $\left(\mathrm{d}_{\mathrm{z}}=40 \mathrm{~mm}\right.$, sekcja pozioma $)$
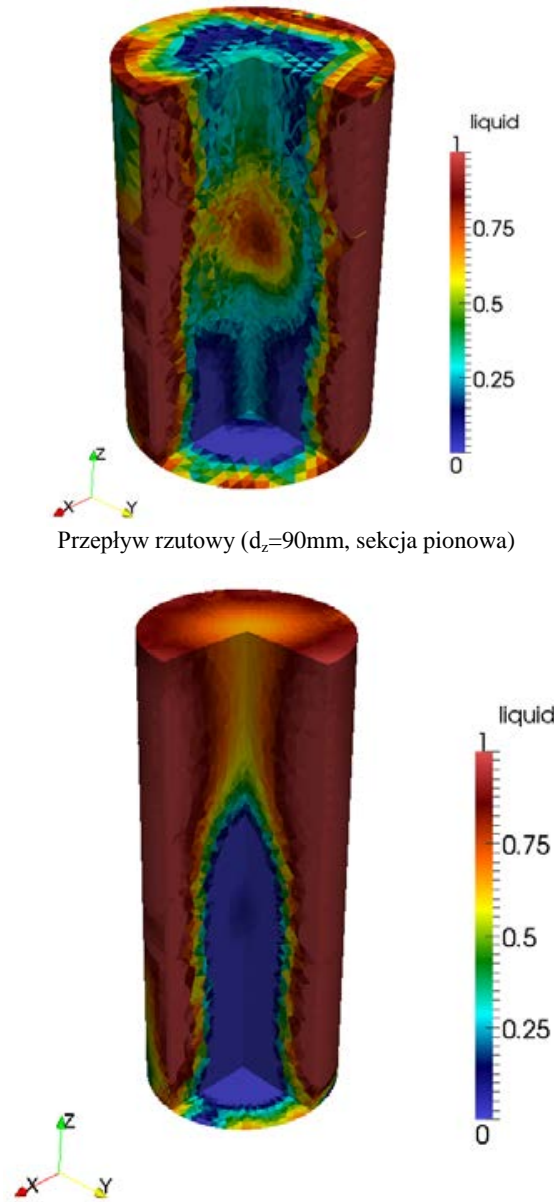

Przepływ rzutowy $\left(\mathrm{d}_{\mathrm{z}}=60 \mathrm{~mm}\right.$, sekcja pionowa), widoczne czoło pęcherza

Rys. 5 (cd). Trójwymiarowe tomogramy struktur przepływów wraz z opisem uzyskanym przez eksperta 


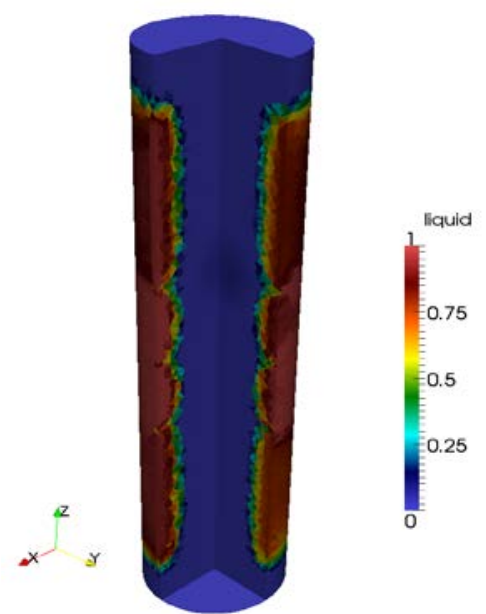

Przepływ pierścieniowy $\left(\mathrm{d}_{\mathrm{z}}=40 \mathrm{~mm}\right.$, sekcja pionowa $)$

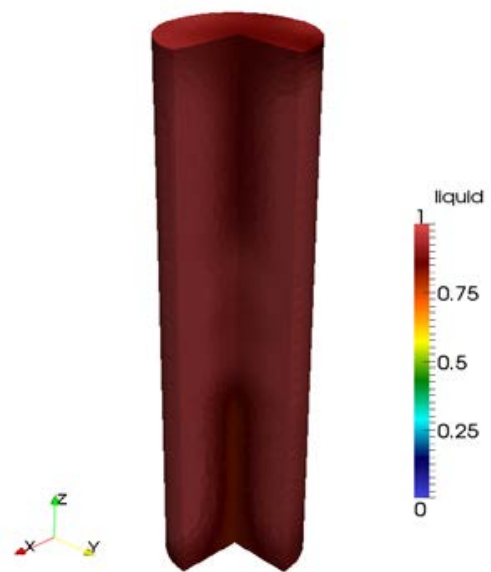

Przepływ pianowy $\left(\mathrm{d}_{\mathrm{z}}=40 \mathrm{~mm}\right.$, sekcja pionowa $) \mathrm{z}$ widocznymi zaburzeniami w górnej i dolnej części czujnika

\section{Eksploracja danych}

W trakcie prac badawczych autorzy stanęli przed istotnym problemem zarządzania znaczną ilością danych. W przypadku samego zagadnienia identyfikacji, całkowity rozmiar danych, zgromadzonych w trakcie realizacji prac badawczych, wyniósł około 121GB (rekonstrukcje trójwymiarowych obrazów, wyznaczone cechy, wizualizacje pakietu VTK). W tym celu dodatkowo opracowano i zaimplementowano autorskie oprogramowanie, pozwalające na szybki podgląd wyznaczonych wartości cech w postaci wykresów oraz łączenie cech w grupy. Widok głównego okna aplikacji został przedstawiony na rysunku 6.

Aplikacja okazała się niezwykle przydatna podczas wstępnej analizy wyników i zapoznawania się $\mathrm{z}$ charakterem poszczególnych cech. Wielokrotnie pomagała również w wychwytywaniu błędów wyznaczania poszczególnych cech.

\section{Podsumowanie}

W ramach prac badawczych zaprojektowano i wykonano system identyfikacji przepływu dwufazowego gaz-ciecz zarówno dla rurociągu poziomego jak i pionowego. W przypadku pomiarów przepływów poziomych niezbędny okazał się blok korekcji obrotu czujnika, aby płaszczyzna lustra cieczy odpowiadała lingwistycznemu pojęciu „poziomo”. Pozwoliło to na naturalnie brzmiące wyrażenia (wartości rozmytych w zmiennych lingwistycznych), a przez to większą kontrolę i przejrzystość bloku przetwarzania i wyznaczania cech obrazów przestrzennych.

W wyniku prac badawczych otrzymano dużą skuteczność identyfikacji struktur przepływów dwufazowych na bazie nieinwazyjnej tomografii pojemnościowej 3D ECT. Jednak złożoność problemu i skala możliwości daje perspektywy do dalszych prac badawczych nad wykorzystaniem zrekonstruowanych obrazów i ich geometrii.

Rys. 5 (cd). Trójwymiarowe tomogramy struktur przeplywów wraz z opisem

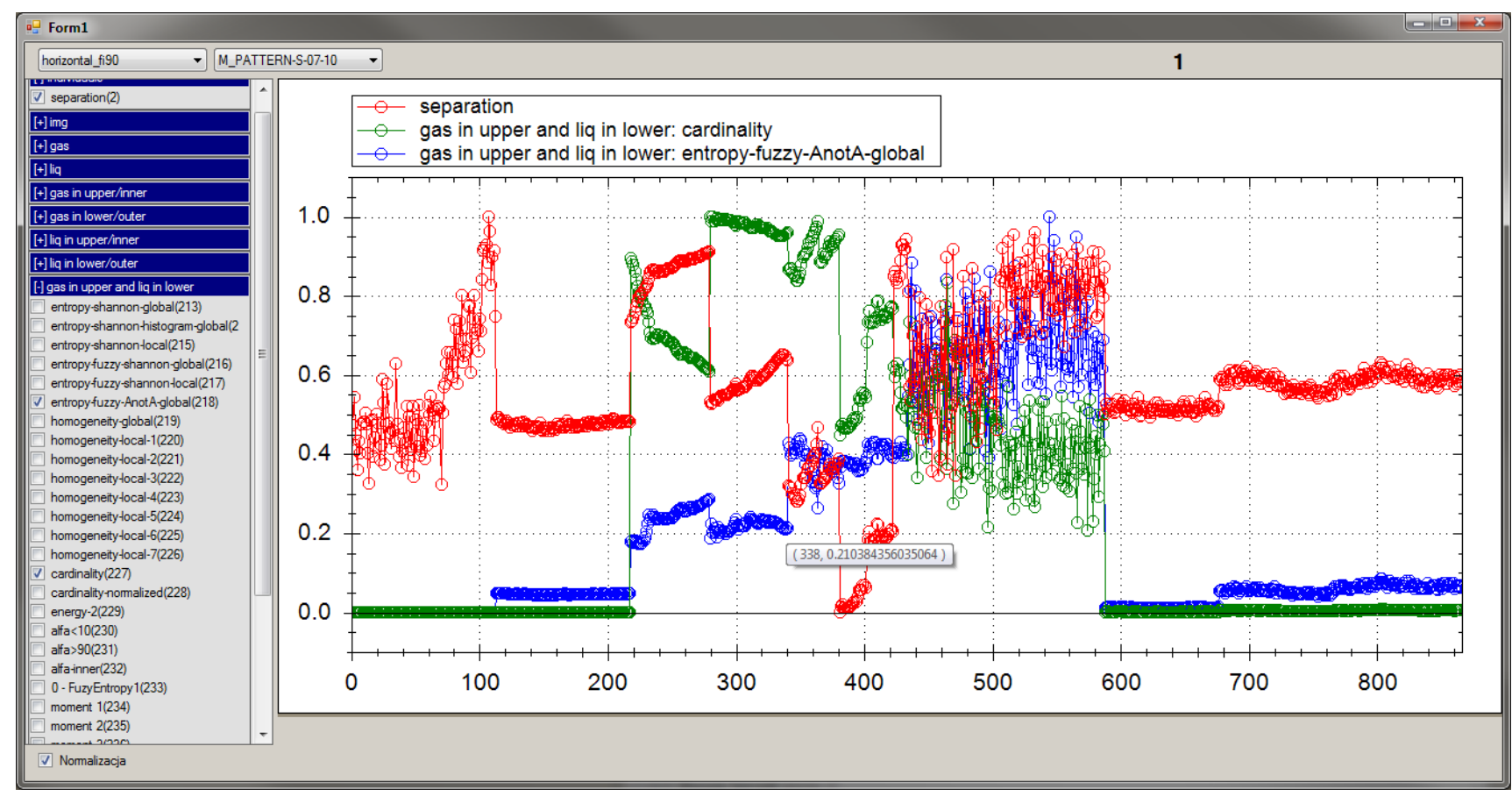

Rys. 6. Widok okna głównego aplikacji do przeglądania wartości cech dla różnych eksperymentów 
Opracowany algorytm może znaleźć zastosowanie w systemach diagnostyki i monitorowania procesów zachodzących w ramach przepływów w instalacjach przemysłowych. Może również stanowić cenne źródło informacji dla systemów automatycznej kontroli i regulacji wydajności instalacji przemysłowych. Uzyskane informacje o przepływach mogą przyczynić się do lepszej kontroli i zapobiegania awariom instalacji przesyłowych.

\section{Podziękowania}

Prace opisane w ramach niniejszego artykułu są finansowane z rządowego projektu naukowo-badawczego NCN nr 4664/B/T02/2010/38

\section{Literatura}

[1] Al-sharhan S. , Karray F. , Gueaieb W., Basir O.: Fuzzy entropy: a brief survey in Fuzzy Systems. The 10th IEEE International Conference on, vol. 3, 2001, pp. 1135-1139.

[2] Banasiak R. , Wajman R. , Fidos H. , Fiderek P. , Jaworski T. , Nowakowski J. , Sankowski D.: System trójwymiarowej tomografii pojemnościowej w zastosowaniu do wyznaczania udziału faz oraz identyfikacji struktur w przepływach mieszanin gaz-ciecz. IAPGOS, 2013, nr 3, 28-31.

[3] Caniere H. , Bauwens B., T’Joen C. , and Paepe M. D.: Probabilistic mapping of adiabatic horizontal two-phase flow by capacitance signal feature clustering. International Journal of Multiphase Flow, vol. 35, no. 7, 2009, pp. 650 - 660.

[4] Cho K.-H., Kim S., Lee Y.-J.: A fast eit image reconstruction method for the two-phase flow visualization. International Communications in Heat and Mass Transfer, vol. 26, no. 5, 1999, pp. 637 - 646 .

[5] Cho K. H., Kim S. , Lee Y. J.: Impedance imaging of two-phase flow field with mesh grouping method. Nuclear Engineering and Design, vol. 204, no. 1-3, 2001, pp. $57-67$.

[6] Cortes C. and Vapnik V., Support-vector networks. Mach. Learn., vol. 20, Sept. 1995, pp. 273-297.

[7] Dunn J. C.: A fuzzy relative of the ISODATA process and its use in detecting compact Well-Separated clusters. Journal of Cybernetics, vol. 3, no. 3, 1973, pp. 32-57.

[8] Evgeniou T., Pontil M. and Elisseeff A.: Leave one out error, stability, and generalization of voting combinations of classifiers. Mach. Learn., vol. 55, Apr. 2004, pp. 71-97.

[9] Guyon I., Weston J., Barnhill S., Vapnik V.: Gene selection for cancer classification using support vector machines. Mach. Learn., vol. 46, Mar. 2002, pp. 389-422.

[10] Kohavi R. and Provost F.: Glossary of terms. Machine Learning, vol. 30, pp. 271-274, 1998. 10.1023/A:1017181826899.

[11]Li H., Zhou Z., Hu C.: Measurement and evaluation of two-phase flow parameters. Instrumentation and Measurement, IEEE Transactions on, vol. 41, apr 1992, pp. $298-303$.

[12] Rahmat M. F., Kamaruddin N. S., Isa M. D.: Flow regime identification in pneumatic conveyor using electrodynamic transducer and fuzzy logic method. Journal on Smart Sensing and Intelligent Systems, vol. 2, 2009, pp. 396-416.

[13] Rifkin R. and Klautau A.: In defense of one-vs-all classification. J. Mach. Learn. Res., vol. 5, Dec. 2004, pp. 101-141.

[14] Tsoukalas L. H., Ishii M., and Mi Y.: A neurofuzzy methodology for impedance-based multiphase flow identification. Engineering Applications of Artificial Intelligence, vol. 10, no. 6, 1997, pp. 545 - 555

[15] Wajman R., Banasiak R.: Nowa metoda tunelowego wyznaczania macierzy wrażliwości dla potrzeb procesu rekonstrukcji obrazów dla trójwymiarowej tomografii pojemnościowej. IAPGOS, 2013, nr 3, 32-37.
[16]Wenyin Z. and Ningde J.: Improved local binary pattern based gas/liquid twophase flow regimes analysis; in Proceedings of the 6th international conference on Fuzzy systems and knowledge discovery - Volume 1, FSKD’09, (Piscataway, NJ, USA), IEEE Press, 2009, pp. 202-206.

[17] Xie D. , Huang Z. , Ji H., Li H.: An online flow pattern identification system for gas-oil two-phase flow using electrical capacitance tomography. IEEE Transactions on Instrumentation and Measurement, vol. 55, no. 5, 2006, pp. 1833-1838.

[18]Zadeh L.: Fuzzy sets. Information and Control, vol. 8, no. 3, pp. 338-353, 1965. zasada rozszerzenia (extension principle).

\section{Mgr inż. Tomasz Jaworski}

e-mail: tjaworski@kis.p.lodz.pl

Mgr inż. Tomasz Jaworski jest doktorantem w Instytucie Informatyki Stosowanej Politechniki Łódzkiej. W swoich pracach zajmuje się zagadnieniami związanymi $\mathrm{z}$ logika rozmytą oraz przetwarzaniem obrazów.

\section{Mgr inż. Pawel Fiderek}

e-mail: p.fiderek@kis.p.lodz.pl

Mgr inż. Paweł Fiderek jest doktorantem w Instytucie Informatyki Stosowanej Politechniki Łódzkiej. W swoich pracach zajmuje się zagadnieniami związanymi z tomografią komputerową, rozpoznawaniem obrazów oraz sztuczną inteligencją zwłaszcza logiką rozmytą.

\section{Dr inż. Radosław Wajman \\ e-mail: rwajman@kis.p.lodz.pl}

Dr inż. Radosław Wajman jest adiunktem w Instytucie Informatyki Stosowanej Politechniki Łódzkiej. Prowadzone badania skupiają się nad zastosowaniem systemów trójwymiarowej tomografii pojemnościowej do nieinwazyjnego monitorowania, diagnozowania oraz automatycznego sterowania praca przemysłowych instalacji przepływów dwu-fazowych.

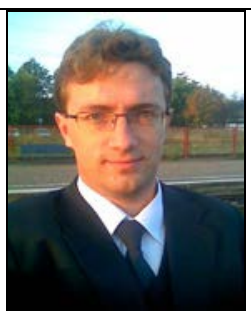

\section{Dr inz. Robert Banasiak}

e-mail: robert.banasiak@p.lodz.pl

Dr inż. Robert Banasiak jest adiunktem w Instytucie Informatyki Stosowanej Politechniki Łódzkiej. W swoich pracach zajmuje się przemysłowymi zastosowaniami elektrycznej tomografii procesowej, a w szczególności problematyką rekonstrukcji obrazów oraz modelowania numerycznego systemów tomografii pojemnościowej. Kierownik grantu 4664/B/T02/2010/38.
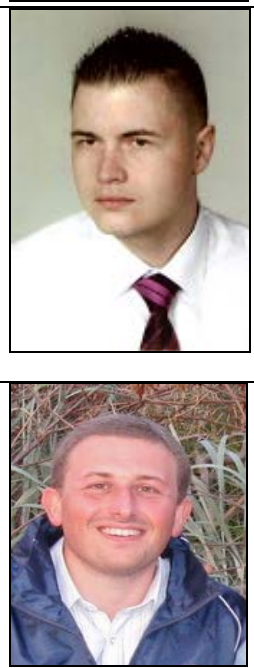